\title{
Bone Defect Animal Model for Hybrid Polymer Matrix Nano Composite as Bone Substitute Biomaterials
}

\author{
Jenan S. Kashan* Wisam K. Hamdan ** Baha Fakhri *** \\ *,** Department of Biomedical Engineering/University of Technology/Baghdad/Iraq \\ *** College of Veterinary Medicine/ University of Baghdad/ Baghdad/Iraq \\ *Email: 70010@uotechnology.edu.iq
}

(Received 26 October 2017; accepted 4 March 2018)

https://doi.org/10.22153/kej.2018.03.004

\begin{abstract}
Addition of bioactive materials such as Titanium oxide $\left(\mathrm{TiO}_{2}\right)$, and incorporation of bio inert ceramic such as alumina $\left(\mathrm{Al}_{2} \mathrm{O}_{3}\right)$, into polyetheretherketone (PEEK) has been adopted as an effective approach to improve bone-implant interfaces. In this paper, hot pressing technique has been adopted as a production method. This technique gave a homogenous distribution of the additive materials in the proposed composite biomaterial. Different compositions and compounding temperatures have been applied to all samples. Mechanical properties and animal model have been studied in all different production conditions. The results of these new $\mathrm{TiO}_{2} / \mathrm{Al}_{2} \mathrm{O}_{3} / \mathrm{PEEK}$ biocomposites with different compositions were promising, mechanical properties within the range of human cortical bone, suitable for load bearing applications. At the same time, in vivo test shows no inflammation reaction with implanted samples. Sustained viability in contact with the sample over seven-day period, showed evidence of excellent biocompatibility in injured rejoins.
\end{abstract}

Keywords: Histology analysis, Hot pressing, Mechanical Properties, Polyetheretherketone (PEEK), $\mathrm{TiO}_{2} / \mathrm{Al}_{2} \mathrm{O}_{3} / \mathrm{PEEK}$ biocomposites.

\section{Introduction}

Defects in bones, can arise duo to human such as, trauma, infection, tumors, or bone damages. Most therapies for bone defects are based, on autografts or allografts. [1]

Many investigations were taken place, to develop biomaterial systems which can be used to repair or replace, natural bone just in case of complicated fracture, previous folks suffer from accidently, fractures, and bone cancer patients [2] At present, bone grafts and replacement, poses challenge to develop biomaterials for scaffold applications" This might be achieved via any of either, endogenous or exogenous materials: auto graft, allograft or a xenograft" [3]

Any proposed biomaterial system for such application, should possess biocompatibility, less inflammation effect, and suitable mechanical properties that should be very close to, natural bone properties to avoid stress shielding, effect which take place when the modulus of elasticity, for biomaterial exceeds that of natural tissue, [4] Poly (ether-ether-ketone) (PEEK) is considering a semi-crystalline, thermoplastic with excellent biocompatibility (fibroblasts and osteoblasts), and as very suitable mechanical properties (strength, stiffness), and superior thermal stability. Modulus of elasticity for PEEK is similar to that of cortical bone, which can reduce stress shielding following implantation. It is also, radiolucent which permits radiographic assessment. The combination of these optimal, properties has made PEEK of great potential for orthopedic application [5]

All previous studies suggest that the $n-\mathrm{TiO}_{2}$ composites have high biocompatibility because of the excellent bioactivity of $\mathrm{TiO}_{2}$ nanoparticles in composites and the morphological properties for the $\mathrm{TiO}_{2}$ particles [6] 
It is believed that $\mathrm{TiO}_{2}$ nanoparticles have higher bioactivity, than conventional (micron) particle sizes. When exposed to Nano phase $\mathrm{TiO}_{2}$ particles, osteoblasts and chondrocytes show a well spread. [7,8]

Hence, ceramic oxides or metallic dispersions are introduced as reinforcing agent. Among the ceramic reinforcement, alpha- $\mathrm{Al}_{2} \mathrm{O}_{3}$ has been utilized in orthopedically application because of its glorious wear resistance, [ 9]

One of the most important issues to be considered, in suggested biomaterials for bone autograft and allograft is their mechanical, properties and their distribution within prepared biomaterial.

In vitro and in vivo testing must take place in order to determine whether a newly developed implant material conforms to the requirements of biocompatibility, mechanical stability and safety. In vitro test results can be difficult to extrapolate, to the invivo situation. For this reason the use of animal models is often an essential step in the testing of orthopedic and dental implants. [10-12] In the present study, $\mathrm{TiO}_{2} / \mathrm{PEEK}$ Nano composites were synthesized for orthopedic application. Alumina used in Nano size to modify mechanical properties for implants. Mechanical properties evaluation has been applied to evaluate implants rather than direct implantation using animal model. Histology path used to analyze biocompatibility and inflammation effect for implants within host tissue environment. [13]

\section{Materials and Methods}

\subsection{Materials}

PEEK powder have an average particle size of $10 \mu \mathrm{m}$, with a nominal density of $1.3 \mathrm{~g} / \mathrm{cm}^{3}$ supplied by Right Fortune Industrial, Limited (Shanghai, China) were used as polymeric matrix. $\mathrm{TiO}_{2}$ and $\mathrm{Al}_{2} \mathrm{O}_{3}$ were used as ceramic fillers, $\mathrm{TiO}_{2}$ (99\% pure) having $40 \mathrm{~nm}$ average particle size and a $4.23 \mathrm{~g} / \mathrm{cm}^{3}$ particle density , while $\alpha$-alumina powder has an average, particle size of $10 \mathrm{~nm}$ and a density of $\left(3.890 \mathrm{~g} / \mathrm{cm}^{3}\right)$. Both ceramic powders were supplied by M.K. Nano (Toronto, Canada).

\subsection{Preparationof $n \mathrm{TiO}_{2} / \mathrm{Al}_{2} \mathrm{O}_{3} /$ PEEK Composite}

A process involving mixing and hot pressing molding were used to prepare the composite samples containing $10 \mathrm{vol}^{2} \mathrm{TiO}_{2} / \mathrm{PEEK}, 20 \mathrm{vol} \%$
$\mathrm{TiO}_{2} / \mathrm{PEEK}, 10$ vol $\% \mathrm{TiO}_{2} / 5$ vol $\% \mathrm{Al}_{2} \mathrm{O}_{3} / \mathrm{PEEK}$, and $20 \mathrm{vol} \% \mathrm{TiO}_{2} / 5$ vol $\% \mathrm{Al}_{2} \mathrm{O}_{3} /$ PEEK.

The $\mathrm{PEEK}, \mathrm{nTiO}_{2}$, and $\mathrm{n}_{2} \mathrm{O}_{3}$ powders were mixed in High-Speed Vibrating Ball Mill at a mixing speed of $500 \mathrm{rpm}$ for 1 hour.

Hot pressing technique was used to prepare samples with $80 \mathrm{MPa}$ compression pressure at different compounding temperatures, $\left(370,380,390\right.$, and $\left.400 C^{\circ}\right)$.

\subsection{Mechanical Properties}

The mechanical properties for all samples have been measured by Instron material testing machine at $0.1 \mathrm{~mm} \cdot \mathrm{min}^{-1} \quad$ speed. The optimal filler content has been determined by evaluating the mechanical properties of the $\mathrm{nTiO}_{2} / \mathrm{Al}_{2} \mathrm{O}_{3} / \mathrm{PEEK}$ composites with different filler contents, which was $20 \mathrm{vol} \% \mathrm{TiO}_{2} / 5 \mathrm{vol} \%$ $\mathrm{Al}_{2} \mathrm{O}_{3} /$ PEEK, all other experaments were done depending on optimal composition.

\subsection{Animals Model}

Eight male (Albino rabbits) having a weight of (2.8-3.2 kilograms) and have an ages ranging between sixteen to twenty weeks have been used. A circular defects with a diameter of eight millimeter were made in each animal limb, the rabits were divided into four groups and an empty control group.

The animals were sacrificed after different periods $(2,4,6$, and 8 weeks) after surgery. The rabbits head were hair removed and disinfected (by using povidone iodine) prior to local anaesthetic, injections at the surgical site (using $2.2 \mathrm{ml}$ Lidocaine Hydrochloride 2\% with adrenaline 1:80,000). Standardized round defects (4number with $8 \mathrm{~mm}$ in diameter) were created.

The holes were filled with the implants. The flaps were repositioned and sutured.

The animals were sacrificed at different periods $(2,4,6$, or 8 weeks) after surgery.

\subsection{Histologic Processing}

Bones were processed for light -microscope histology to establish their histogenesis by using the histokinate. This processing involve the following steps:

1-Dehydration: is the removal of all extractable water by alcohol upgrading starting from $70 \%$, through absolute alcohol $(70 \%, 80 \%, 90 \%$,and $100 \%$ ), twice for 2 hours each time for each step to improve complete dehydration. 
2-Clearing: As a dehydrator is removed, the tissue cleared, becoming translucent by using of xylene twice for 1.5 hour for each time.

3-Impergnation: Is the complete removal of xyline by substitution of paraffin penetration through the tissue, used twice for 2 hours each time in paraffin bath adjusted on 58C.

4-Embedding: The processed tissue was oriented in melted paraffin, which provides affirm medium for keeping intact all parts of the bone tissue when sectioned.

5- Cutting: serial paraffin sections of 6-8 um were cut by using rotary microtome.

6-staining of histological sections, routine histological stain of Harris hematoxylin and Eosin stain.

\section{Results and Discussion}

\subsection{Mechanical Properties}

Measured mechanical properties for implants as comparison with that of natural bone are listed in table 1. Figures 1-3 show the relationship between compounding temperature vs.

Modulus of elasticity, tensile strength, and compressive strength respectively.
Results for mechanical properties show very close values with that for natural bone which give great indication about proposed composite, as promising replacement for natural bone especially in case of victims of wore, care bombing, and old aged people in Iraq and other countries. These findings indicate also that the effect of stress shielding is very limited here $[14,15]$ which will nominate proposed biomaterial as suitable replacement for damaged natural bone.

\subsection{In Vivo Test Results}

Histological path for implants are shown in figures 4-8. These figures show that, the healing process for all surgery places was without any abnormal bleeding or infection. In the same time no inflammation evidence were.

Very small amount of the formation of new bone was observed in the control group. All defects were naturally filled by the brain tissues as well as, the overlying periosteum.

Normal growth were noticed in all implants which give strong indication that this biocomposite system can be used significaly in bone repair and replacement.

Table 1,

comparison between measured properties and natural bone density and mechanical Properties

\begin{tabular}{lllll}
\hline Sp. composition & $\begin{array}{l}\text { Compounding } \\
\text { Temp.C }\end{array}$ & $\begin{array}{l}\text { Modulus of elasticity } \\
\text { (GPa) }\end{array}$ & $\begin{array}{l}\text { Tensile strength } \\
\text { (MPa) }\end{array}$ & $\begin{array}{l}\text { Compressive } \\
\text { strength(MPa) }\end{array}$ \\
\hline cortical bone(compact) & & $10-20$ & $131-224$ & $131-205$ \\
Cancellous bone(trabecular) & & $10-3000(\mathrm{MPa})$ & $50-100$ & $70-280$ \\
& 370 & 6 & 140 & 156 \\
$10 \mathrm{vol} \% \mathrm{TiO}_{2} / \mathrm{PEEK}$ & 380 & 6.8 & 150 & 159 \\
& 390 & 7 & 155 & 163 \\
& 400 & 7.4 & 162 & 168 \\
& 370 & 10 & 170 & 182 \\
$20 \mathrm{vol} \% \mathrm{TiO}_{2} / \mathrm{PEEK}$ & 380 & 11 & 176 & 189 \\
& 390 & 12.5 & 178 & 194 \\
& 400 & 13 & 180 & 203 \\
$10 \mathrm{vol} \% \mathrm{TiO}_{2} / 5 \mathrm{vol} \%$ & 370 & 15 & 184 & 209 \\
$\mathrm{Al}_{2} \mathrm{O}_{3} / \mathrm{PEEK}$ & 380 & 15.7 & 188 & 212 \\
& 390 & 17 & 191 & 215 \\
$20 \mathrm{vol} \% \mathrm{TiO}_{2} / 5$ & 400 & 17.3 & 192 & 240 \\
$\mathrm{vol}_{2} \mathrm{Al}_{2} \mathrm{O}_{3} / \mathrm{PEEK}$ & 370 & 19 & 210 & 243 \\
& 380 & 19.8 & 215 & 252 \\
\hline
\end{tabular}




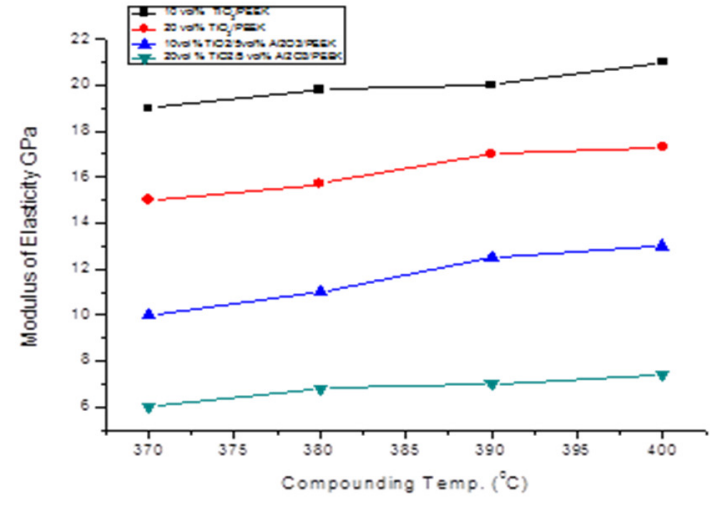

Fig. 1. Relationship between Compounding temperature and modulus of elasticity for different compositions.

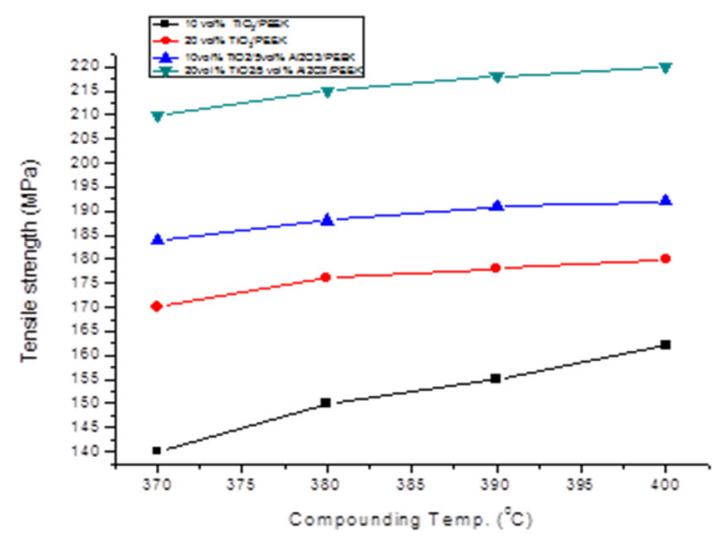

Fig. 2. Relationship between compounding temperature and tensile strength for different compositions .

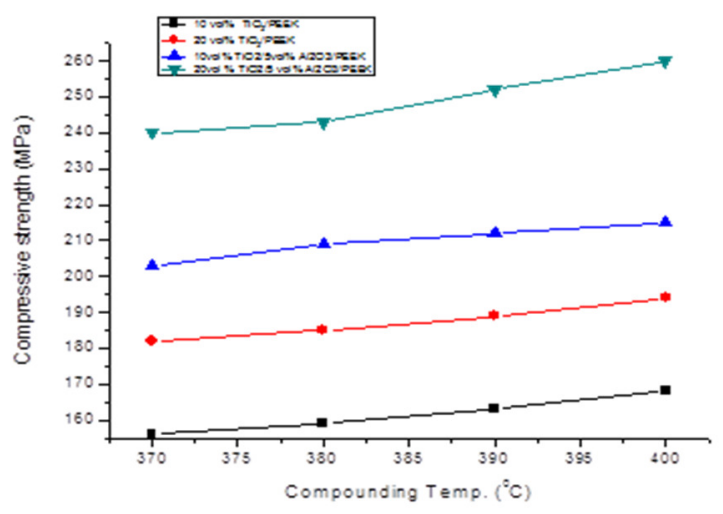

Fig. 3. Relationship between compounding temperature and compressive strength for different compositions.

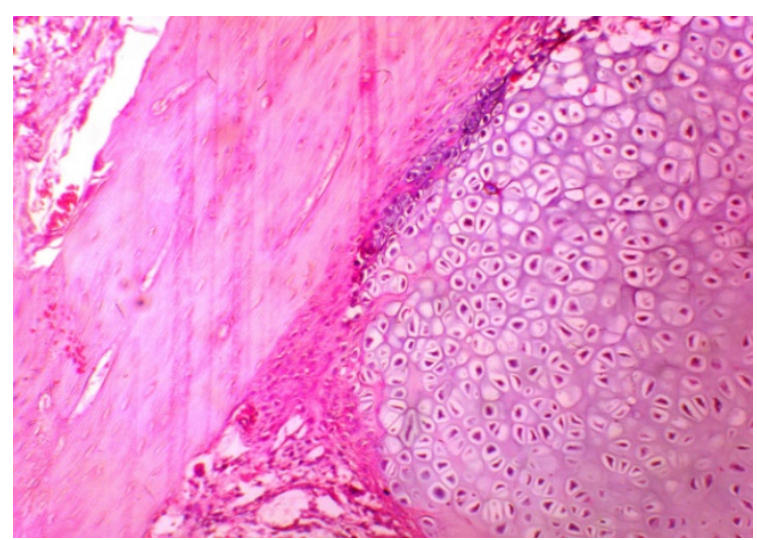

Fig. 4. Microphotographs of the control show cartilage ingrowth and fibrous tissue stain with H\&E (x 400).

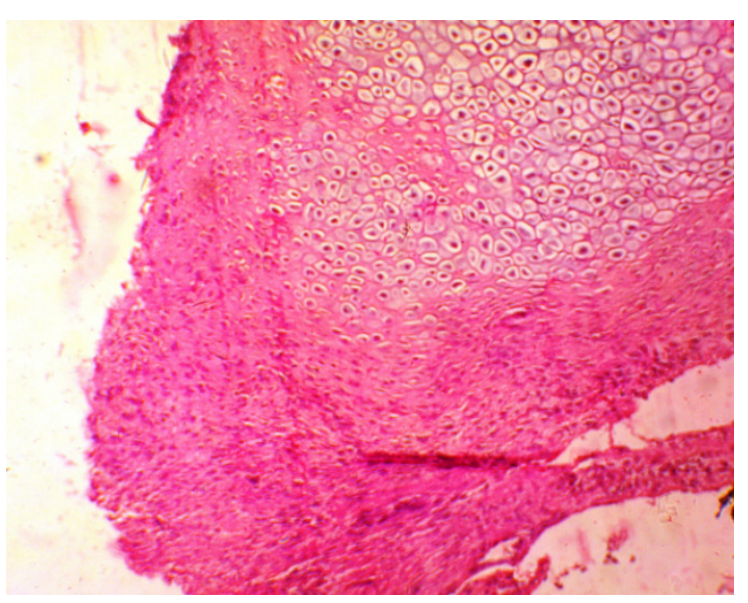

Fig. 5. Microphotographs of the bone 2 weeks after implantation show cartilage ingrowth and fibrous tissue, stain with $\mathrm{H \& E}$ (x 100).

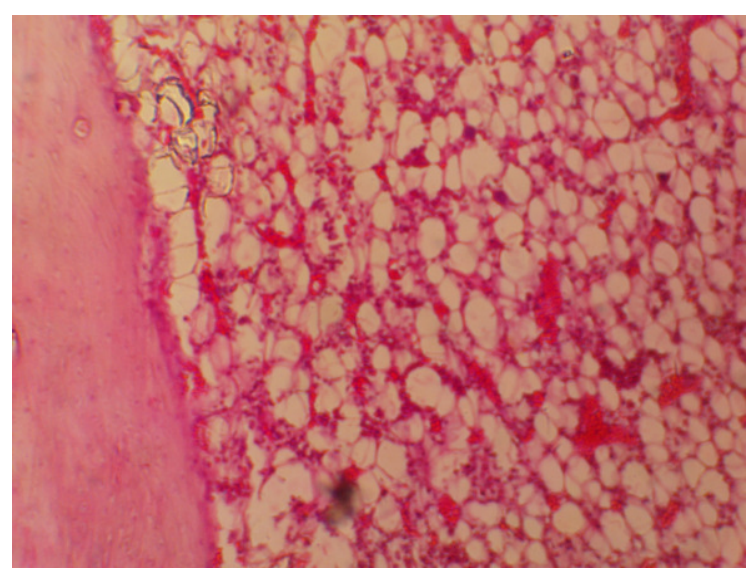

Fig. 6. Microphotographs of the bone 4 weeks after implantation show normal bone morrow without inflammation, stain with $\mathrm{H} \& \mathrm{E}$ (x100) . 


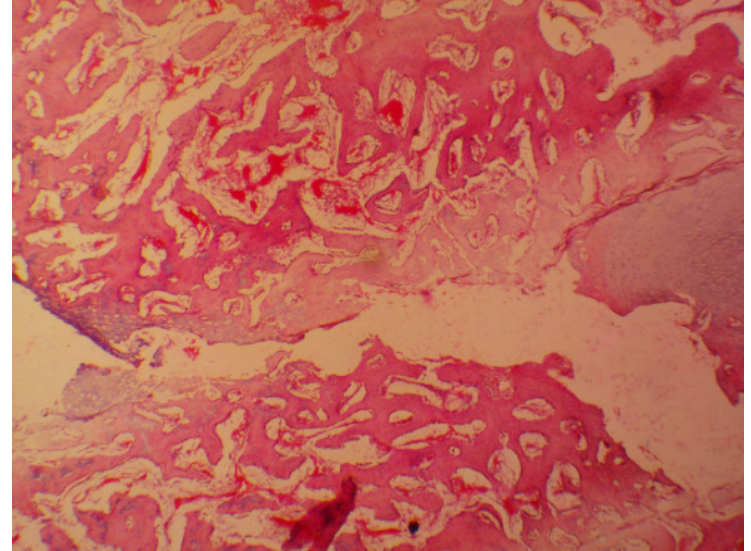

Fig. 7. Microphotographs of the bone 4 weeks after implantation inert material show no inflammatory cells, stain with $\mathrm{H} \& \mathrm{E}$ (x100).

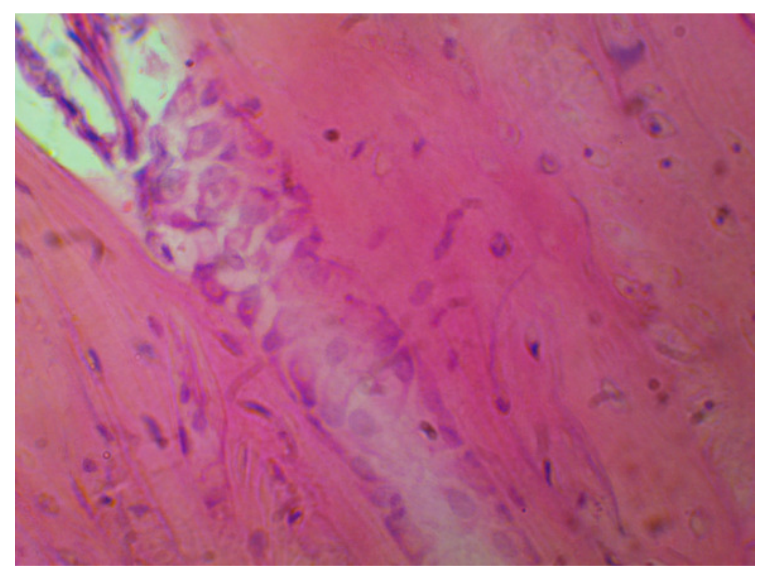

Fig. 8. Microphotographs of the bone 8 weeks after implantation inert material show few fibrous tissue and cartilage, stain with H\&E (x 400).

\section{Conclusions}

From listed results we can conclude that $\mathrm{TiO}_{2} / \mathrm{Al}_{2} \mathrm{O}_{3} /$ PEEK composites can be a suitable replacement choice in case of complex fractured bone when natural tissues cannot restore their normal structure,rather than ability to use such a biomaterials in artificial limbs manufacturing because of their superior mechanical and biological properties. Best mechanical properties were achieved at $20 \mathrm{vol} \% \mathrm{TiO}_{2} / 5 \mathrm{vol} \% \mathrm{Al}_{2} \mathrm{O}_{3} /$ PEEK.

Animal model shows very suitable biological response for implanted samples which is a strong indication about biocompatibility for the proposed biocomposite system.

\section{References}

[1]M.Vaz, H. Canhão, and J. Fonseca, Bone: A Composite Natural Material, Advances in Comp. Mater. - Analysis of Natural and Man-Made Materials, Dr. Pavla Tesinova (Ed.),ISBN: 978-953-307-449-8, InTech, Available from: http://www.intechopen.com/books/

[2]P. Fratzl, H.Gupta, E.Paschalis, and P.Roshger, Structure and mechanical quality of the collagen-mineral nanocomposite in bone. Journal of Materials Chemistry, Vol.14, No.14, pp. 2115-2123, 2004, ISSN 0959-9428.

[3]P.Fratzl, and R.Weinkamer, Nature's hierarchical materials. Progress in Materials Science, Vol.52, No.8, pp. 12631334, 2007.

[4]Z.Fratzl , N.; Roschger, P; Gourrier, A.; Weber, M.; Misof, B.; Loveridge, N.; Reeve, J.; Klaushofer, K. \& Fratzl, L.(2009).Combination of Nano indentation and quantitative backscattered electron imaging revealed altered bone material properties associated with femoral neck fragility. Calcified Tissue International, Vol.85, No.4, pp. 335-343, 2009.

[5][5] H. Wang, T. Lu, F. Meng, H. Zhu, and $\mathrm{X}$. Liu, "Enhanced osteoblast responses to poly ether ether ketone surfacemodified by water plasma immersion ion implantation," Colloids and Surfaces B: Biointerfaces, vol. 117, pp. 89-97, 2014.

[6]C.-M. Han, E.-J. Lee, H.-E. Kim et al,“The electron beam deposition of titanium on polyetheretherketone (PEEK) and the resulting enhanced biological properties," Biomaterials, vol. 31 , no. 13, pp. 34653470, 2010.

[7]K. L.Wong, C. T.Wong,W. C. Liu et al., "Mechanical properties and in vitro response of strontium-containing hydroxyapatite/polyetheretherketone composites," Biomaterials, vol. 30, no. 2324, pp. 3810-3817, 2009.

[8]X. Wu, X. Liu, J. Wei, J. Ma, F. Deng, and S. Wei, "Nano- TiO2/PEEK bioactive composite as a bone substitute material: in vitro and in vivo studies," International Journal of Nanomedicine, vol. 7, pp. 12151225, 2012.

[9]H.-K. Tsou, P.-Y. Hsieh, C.-J. Chung, C.H. Tang, T.-W. Shyr, and J.-L. He, "Lowtemperature deposition of anatase $\mathrm{TiO} 2$ on medical grade polyetheretherketone to 
assist osseous integration," Surface and Coatings Technology, vol. 204, no. 6-7, pp.1121-1125, 2009.

[10] Y. Zhao, H. M. Wong, W. Wang etal,"Cytocompatibility, sseointegration, and bioactivity of three-dimensional porous and nanostructured network on polyetheretherketone," Biomaterials, vol. 34, no. 37, pp. 9264-9277, 2013.

[11] H. Garg, G. Bedi, and A. Garg, "Implant surface modifications: a review," Journal of Clinical and Diagnostic Research, vol. 6, no. 2, pp. 319-324, 2012.

[12] F. Awaja, D. V. Bax, S. Zhang, N. James, and D. R. McKenzie, "Cell adhesion to PEEK treated by plasma immersion ion implantation and deposition for active medical implants,"Plasma Processes and Polymers, vol. 9, no. 4, pp. 355-362, 2012.

[13] A. H. C. Poulsson, D. Eglin, S. Zeiter et al., "Osseointegration of machined, injection moulded and oxygen plasma modified PEEK implants in a sheep model," Biomaterials, vol. 35, no. 12, pp. 3717-3728, 2014.
[14] Z. Novotna, A. Reznickova, S. Rimpelova,M. Vesely, Z. Kolska, and V. Svorcik, "Tailoring of PEEK bioactivity for improved cell interaction: plasma treatment in action," RSC Advances, vol. 5, no. 52, pp. 41428-41436, 2015.

[15] D.M.Devine, J.Hahn, R. G. Richards, H. Gruner, R. Wieling, and S. G.Pearce, "Coating of carbon fiber-reinforced polyetheretherketone implants with titanium to improve bone apposition,"Journal of Biomedical MaterialsResearchB:Applied

Biomaterials, vol. 101, no. 4, pp. 591598, 2013. 


\title{
دراسة معالجة الفشل في العظام باستخدام مادة مركبة متعددة ذات اساس من البوليمر

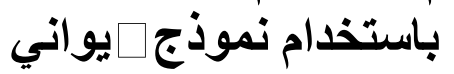

\author{
بهاء فخري \\ جن*ان ستار خشان* \\ ان

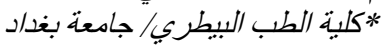 \\ 70010@uotechnology.edu.iq البريد الاككترونية
}

الخلاصة

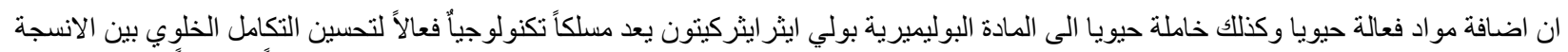

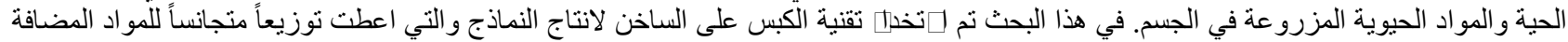

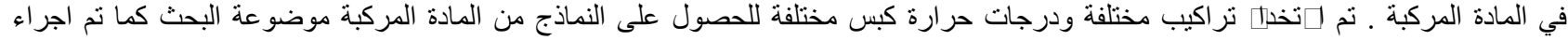

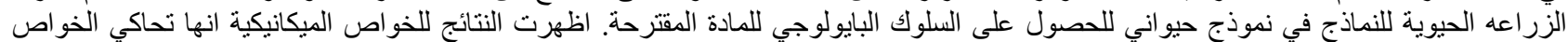

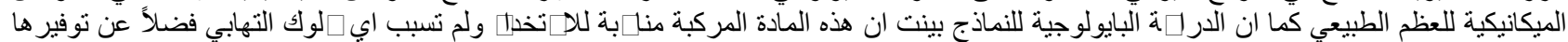

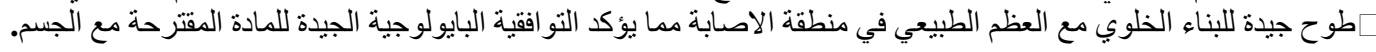

